\title{
Factors associated with the intellectual ability of children born to women with high risk pregnancies
}

\author{
M OUNSTED, V A MOAR, J COCKBURN, C W G REDMAN
}

\begin{abstract}
The intellectual abilities of 242 children born to women who had been hypertensive during pregnancy were assessed at the age of $7 \frac{1}{2}$ years. Associations between 15 maternal, fetal, perinatal, postnatal and environmental factors, and test scores were investigated. After adjustment for confounding variables children in the upper social classes, born to non-smokers, who were first born, breast fed, and with birth weights above the 10th centile had significantly higher scores in some aspects of ability than the rest. Children whose mothers had developed superimposed pre-eclampsia had higher scores than those whose mothers had not suffered preeclampsia; and children delivered by elective caesarean section had lower scores than those delivered spontaneously. In a small subgroup of women with particularly high risk pregnancies perinatal mortality had been 10 times greater than in the rest of the sample. At $7 \frac{1}{2}$ years the intellectual ability of the survivors in this subgroup did not differ from that of the rest.

These findings do not support the notion that there is a quantitative continuum of "reproductive casualty" from mortality to morbidity.
\end{abstract}

\section{Introduction}

With steadily decreasing perinatal mortality attention in the past decade has turned to the identification of factors predisposing to severe handicap and also those which might prevent children from achieving their full developmental potentials. Population studies have related antecedent and environmental factors with certain specific aspects of behaviour and development in childhood. ${ }^{2}$ Obstetric, neonatal, and developmental "optimality" scores have been used to examine the effects of high risk pregnancies on child development. ${ }^{3-9}$ Others have examined the effects of specific factors such as maternal smoking, ${ }^{10-12}$ method of delivery, ${ }^{13}{ }^{14}$ asphyxia at birth,,$^{15-17}$ hyperbilirubinaemia in the neonatal period, ${ }^{18}$ and method of infant feeding. ${ }^{19}{ }^{20}$ Studies have also been made of the postnatal development of preterm and small for dates babies. ${ }^{21-24}$ The findings of these studies have often been inconclusive owing to variations in methodology, in the populations under consideration, and in the obstetric and neonatal techniques available at the time of the children's birth. Furthermore, in many cases no account has been taken of confounding between variables.

We have been examining prospectively the growth and development of children born to women participating in a large controlled trial of the treatment of maternal hypertension

University of Oxford, John Radcliffe Hospital, Headington, Oxford OX3 9DU

M OUNSTED, DM, MRCP, lecturer in early human development, department of paediatrics

V A MOAR, AIST, research assistant, department of paediatrics

J COCKBURN, BA, psychologist, department of paediatrics

C W G REDMAN, MRCP, lecturer in obstetric medicine, Nuffield department of obstetrics and gynaecology

Correspondence to: Dr M Ounsted. in pregnancy. ${ }^{25-30} \mathrm{We}$ have now reanalysed our data to examine all the maternal, pregnancy, perinatal, and postnatal factors which might affect the intellectual state of the children at the age of $7 \frac{1}{2}$ years.

\section{Patients and methods}

Full details of the selection and management of the patients were given in the original paper on fetal outcome. ${ }^{25}$ The criterion for the majority $(79 \%)$ who entered the trial before 28 weeks of gestation was a blood pressure of $140 / 90 \mathrm{~mm} \mathrm{Hg}$ or more on two occasions separated by at least 24 hours. After 28 weeks the criterion was raised to $150 / 95 \mathrm{~mm} \mathrm{Hg}$. Twenty six patients were excluded from the randomised trial because of "severe" hypertension (170/ $110 \mathrm{~mm} \mathrm{Hg}$ or more) or because they were already receiving hypotensive treatment or had other medical or obstetric complications. Their pregnancies were monitored in the same way as the rest, however, and their 19 living infants were included in the follow up studies from birth.

Of the children who survived the neonatal period, $242(96.8 \%)$ were extensively examined at the age of $7 \frac{1}{2}$ years. Ten tests selected from the British ability scales (BAS) ${ }^{31}$ were used to assess the children's

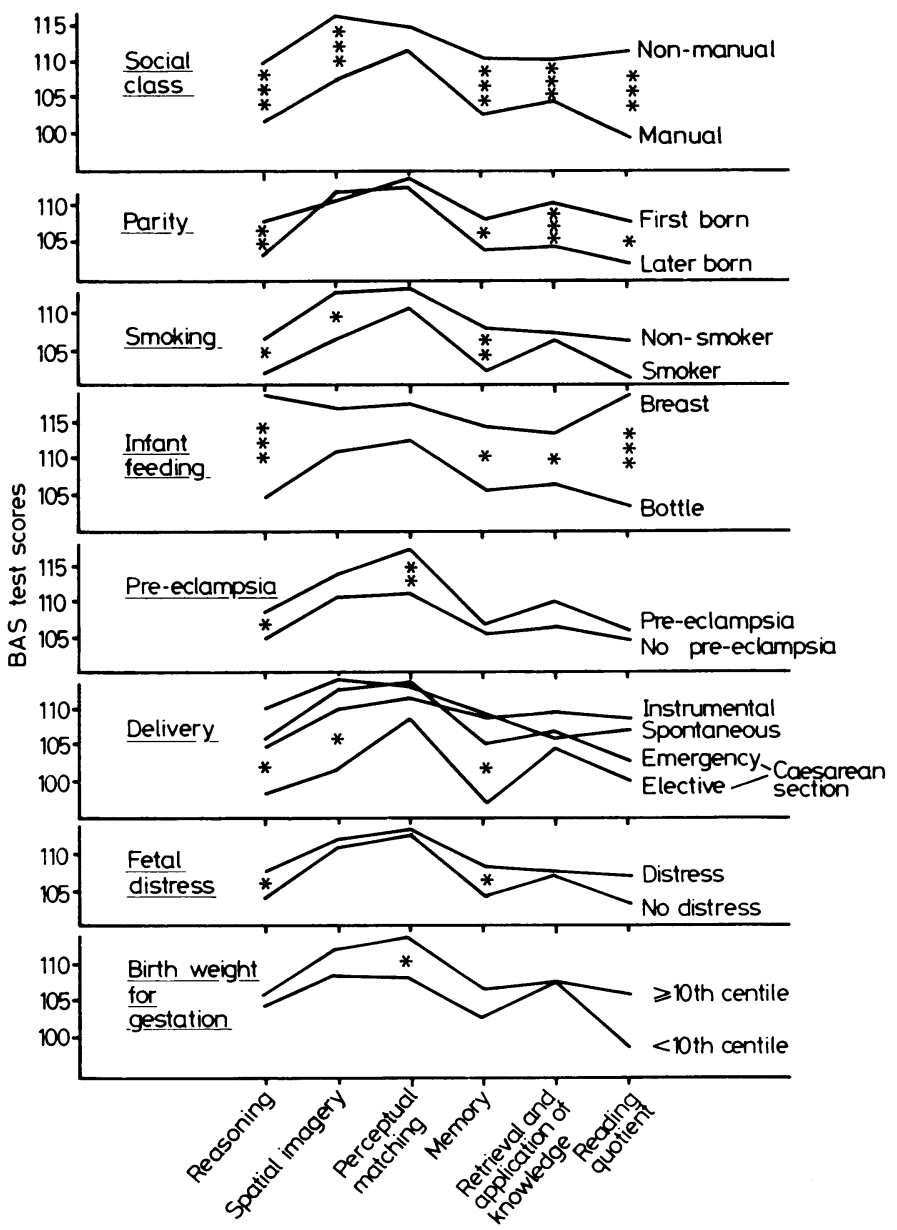

BAS scores according to associated factors. ${ }^{*} \mathrm{p}<0.05$. ${ }^{* *} \mathrm{p}<0.01 .{ }^{* * *} \mathrm{p}<0.001$. 
development. They were grouped into pairs representing five different intellectual "processes" (reasoning, spatial imagery, perceptual matching, memory, and retrieval and application of knowledge). The ability scores for each test were converted to $T$ scores with a mean value of 50 and a standard deviation of 10 . Thus the standardised mean value for each "process" was 100 . The Holborn reading test was also administered and a reading quotient obtained.

Fifteen maternal, fetal, perinatal, postnatal, and environmental factors were selected for investigation. The definitions and cut off points taken for these variables have been described. ${ }^{30}$ 32-34 Analyses of variance, $t$ tests, the $\chi^{2}$ test, and multiple regression techniques were used to analyse the data where appropriate.

\section{Results}

No significant differences were found in the mean reading quotient or for any of the five processes according to maternal age, treatment with methyldopa (or not), preterm delivery (or not), bleeding during pregnancy, asphyxia at birth, or problems in the neonatal period. Straight analyses according to sex just failed to achieve significance; however, we had previously found that when adjustment was made for social class girls had higher reading quotients than boys $(p<0.05)$, and we therefore included this factor in the final analyses. found according to fetal distress in labour (or not) and weight for gestational age at birth (below or above the 10th centile).

The effects of all these factors (including sex) were next considered simultaneously by multiple regression analysis, thus giving an estimate of the "net" effect of each variable taking account of all the other factors. For each variable one category was taken as baseline, with a value of zero. Table I gives the results. Values of significance were obtained by estimating the reduction in explained variation when each variable was omitted in turn from the "full" regression model.

The contribution of social class to four of the six aspects of ability remained substantially unchanged but those due to parity and smoking were reduced, and the difference was significant for only one process in each case. Children whose mothers had suffered from pre-eclampsia still had significantly higher scores for perceptual matching, and those who had been breast fed had significantly higher scores for reasoning and, to a less extent, for reading. When comparisons were made with spontaneous vaginal deliveries children delivered by elective caesarean section had lower scores in all aspects; the differences were significant for reasoning and memory tests and highly significant for spatial imagery. Children who had been small for dates babies did worse in perceptual matching, and boys had lower reading quotients. After adjustment for other factors associations between fetal distress in labour and ability at $7 \frac{1}{2}$ years disappeared.

In the group of 26 hypertensive women who were excluded from

TABLE I-Differences in BAS scores due to associated variables (in each case adjustment has been made for all the other variables)

\begin{tabular}{|c|c|c|c|c|c|c|}
\hline & Reasoning & $\begin{array}{r}\text { Spatial } \\
\text { imagery }\end{array}$ & $\begin{array}{l}\text { Perceptual } \\
\text { matching }\end{array}$ & Memory & $\begin{array}{c}\text { Retrieval and } \\
\text { application of knowledge }\end{array}$ & $\begin{array}{l}\text { Reading } \\
\text { quotient }\end{array}$ \\
\hline $\begin{array}{l}\text { Social classt: } \\
\text { Non-manual }(n=106) \\
\text { Manual }(n=129)\end{array}$ & $\begin{array}{c}0 \\
-6 \cdot 0^{* *}\end{array}$ & $\begin{array}{l}0 \\
-7 \cdot 8^{* * * *}\end{array}$ & $\begin{array}{c}0 \\
-1.5\end{array}$ & $\begin{array}{c}0 \\
-5 \cdot 9 * *\end{array}$ & $\begin{array}{c}0 \\
-3.5\end{array}$ & $\begin{array}{c}0 \\
-9 \cdot 8^{* * *}\end{array}$ \\
\hline $\begin{array}{l}\text { Parity: } \\
\text { First born }(n=105) \\
\text { Later born }(n=137)\end{array}$ & $\begin{array}{c}0 \\
-3.0\end{array}$ & $\begin{array}{c}0 \\
+2.6\end{array}$ & $\begin{array}{c}0 \\
-0.1\end{array}$ & $\begin{array}{c}0 \\
-1.4\end{array}$ & $\begin{array}{c}0 \\
-4 \cdot 1^{*}\end{array}$ & $\begin{array}{c}0 \\
-3 \cdot 2\end{array}$ \\
\hline $\begin{array}{l}\text { Smoking: } \\
\text { None }(n=174) \\
\text { Some }(n=68)\end{array}$ & $\begin{array}{c}0 \\
-2 \cdot 8\end{array}$ & $\begin{array}{c}0 \\
-3 \cdot 1\end{array}$ & $\begin{array}{c}0 \\
-2 \cdot 1\end{array}$ & $\begin{array}{c}0 \\
-5 \cdot 3^{*}\end{array}$ & $\begin{array}{ll}0 \\
-0.9\end{array}$ & $\begin{array}{l}0 \\
-2 \cdot 5\end{array}$ \\
\hline $\begin{array}{l}\text { Infant feedingt: } \\
\text { Breast }(n=21) \\
\text { Bottle }(n=218) \\
\text { Pre-eclampsia: }\end{array}$ & $\begin{array}{c}0 \\
-11 \cdot 0 * * *\end{array}$ & $\begin{array}{c}0 \\
-2 \cdot 6\end{array}$ & $\begin{array}{l}0 \\
-2 \cdot 3\end{array}$ & $\begin{array}{c}0 \\
-6 \cdot 6\end{array}$ & $\begin{array}{l}0 \\
-5 \cdot 4\end{array}$ & $\begin{array}{c}0 \\
-10 \cdot 6^{*}\end{array}$ \\
\hline $\begin{array}{l}\text { Mild or none }(n=176) \\
\text { Moderate to severe }(n=56)\end{array}$ & $\begin{aligned} & 0 \\
+ & 2 \cdot 6\end{aligned}$ & $\begin{aligned} & 0 \\
+ & 2.5\end{aligned}$ & $\begin{array}{l}0 \\
+6 \cdot 7^{* * *}\end{array}$ & $\begin{array}{l}0 \\
+0.4\end{array}$ & $\begin{aligned} & 0 \\
+ & 1 \cdot 4\end{aligned}$ & $\begin{aligned} & 0 \\
+ & 1 \cdot 1\end{aligned}$ \\
\hline $\begin{array}{l}\text { Delivery: } \\
\text { Spontaneous }(n=132) \\
\text { Instrumental }(n=58) \\
\text { Elective caesarean section }(n=24) \\
\text { Emergency caesarean section }(n=28)\end{array}$ & $\begin{array}{l} \\
\quad 0 \\
-2 \cdot 2 \\
-7 \cdot 5 * \\
+2 \cdot 4\end{array}$ & $\begin{array}{l}0 \\
-1.9 \\
-15 \cdot 0 * * * \\
+3.6\end{array}$ & $\begin{aligned} & 0 \\
- & 1 \cdot 5 \\
- & 6 \cdot 3 \\
+ & 1 \cdot 2\end{aligned}$ & 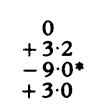 & $\begin{aligned} & 0 \\
+ & 1.5 \\
- & 4 \cdot 7 \\
- & 1.8\end{aligned}$ & $\begin{aligned} & 0 \\
+ & 3.6 \\
- & 1.5 \\
+ & 3.9\end{aligned}$ \\
\hline $\begin{array}{l}\text { Fetal distress: } \\
\text { None }(n=144) \\
\text { Some }(n=98)\end{array}$ & $\begin{array}{c}0 \\
+2 \cdot 1\end{array}$ & $\begin{array}{c}0 \\
-1.9\end{array}$ & $\begin{array}{c}0 \\
-0.4\end{array}$ & $\begin{array}{l}0 \\
+0.4\end{array}$ & $\begin{array}{c}0 \\
-1 \cdot 3\end{array}$ & $\begin{array}{c}0 \\
+1.3\end{array}$ \\
\hline $\begin{array}{l}\text { Birth weight for gestation: } \\
\geqslant 10 \text { th centile }(n=218) \\
<10 \text { th centile }(n=24)\end{array}$ & $\begin{array}{c}0 \\
-0.1\end{array}$ & $\begin{array}{c}0 \\
-1 \cdot 3\end{array}$ & $\begin{array}{l}0 \\
-8 \cdot 1^{* *}\end{array}$ & $\begin{array}{c}0 \\
-2 \cdot 6\end{array}$ & $\begin{array}{l}0 \\
+1.4\end{array}$ & $\begin{array}{c}0 \\
-5.5\end{array}$ \\
\hline $\begin{array}{l}\text { Sex: } \\
\quad \text { Male }(n=133) \\
\quad \text { Female }(n=109)\end{array}$ & $\begin{array}{l}0 \\
+1.2\end{array}$ & $\begin{array}{c}0 \\
-2 \cdot 5\end{array}$ & $\begin{array}{c}0 \\
+2 \cdot 3\end{array}$ & $\begin{array}{l}0 \\
-2.5\end{array}$ & $\begin{array}{c}0 \\
-1 \cdot 7\end{array}$ & $\begin{array}{l}0 \\
+6 \cdot 2 *\end{array}$ \\
\hline
\end{tabular}

$* \mathrm{p}<0.05 .^{* *} \mathrm{p}<0.01 . * * * \mathrm{p}<0.001$

†Information not available in three cases.

The figure shows those factors for which significant differences were found in one or more aspects of ability. Social class had a highly significant effect on most intellectual processes, and first born children were also superior to later born in four out of six aspects of ability. The effect of maternal smoking during pregnancy was clear but relatively mild; and children who had been breast fed for at least two months had significantly higher scores, particularly for reading and reasoning. Children whose mothers had developed superimposed pre-eclampsia performed better in all aspects, and the difference in mean scores was significant for reasoning and perceptual matching. Method of delivery also showed significant differences, which were due to those children delivered by elective caesarean section scoring lower than the other three categories. The reasons for elective section (rather than induction of labour) were previous caesarean section (11 cases), unfavourable cervix (six), urgency because of deterioration in maternal condition (three), unstable lie (two), poor obstetric history associated with bicornuate uterus (one), and breech presentation (one). There were eight preterm and 16 term infants, but no differences were found within this subgroup in the average of the six test scores between preterm (99.6 SD 14.6) and term children $(103.6 \mathrm{SD} 13 \cdot 1)$ at $7 \frac{1}{2}$ years $(t=0 \cdot 69)$. Small differences were also the randomised trial because of additional complications the perinatal mortality rate had been $269 / 1000$ births compared with $25 / 1000$ among the rest $\left(7 / 26\right.$ and $6 / 238$, respectively: $\left.\chi^{2}=24.8 ; p<0.001\right)$. Eighteen of the 19 survivors were seen again at $7 \frac{1}{2}$ years. When the mean scores of this "special risk" group were compared with those of the rest of the sample no significant differences were found for any aspect of ability (table II). The use of analysis of variance techniques to adjust for social class and sex did not appreciably alter the findings.

TABLE II-BAS scores in "special risk" group compared with rest of sample

\begin{tabular}{|c|c|c|c|c|c|c|}
\hline & \multicolumn{2}{|c|}{$\begin{array}{l}\text { Special group } \\
(\mathrm{n}=18)\end{array}$} & \multicolumn{2}{|c|}{$\begin{array}{c}\text { Remainder } \\
(n=224)\end{array}$} & \multirow{2}{*}{$t$} & \multirow{2}{*}{$\mathbf{p}$} \\
\hline & Mean & SD & Mean & SD & & \\
\hline $\begin{array}{l}\text { Reasoning } \\
\text { Spatial imagery } \\
\text { Perceptual matching } \\
\text { Memory } \\
\text { Retrieval and application of knowledge } \\
\text { Reading quotient }\end{array}$ & $\begin{array}{r}104.3 \\
110.5 \\
111.6 \\
106.5 \\
103.1 \\
98.6\end{array}$ & $\begin{array}{l}19.4 \\
21.2 \\
11.3 \\
18.3 \\
12.7 \\
18.7\end{array}$ & $\begin{array}{l}105 \cdot 6 \\
111 \cdot 7 \\
113 \cdot 6 \\
106 \cdot 5 \\
108 \cdot 1 \\
105 \cdot 8\end{array}$ & $\begin{array}{l}14 \cdot 1 \\
17 \cdot 7 \\
14 \cdot 3 \\
16 \cdot 3 \\
13 \cdot 4 \\
20 \cdot 0\end{array}$ & $\begin{array}{l}0.38 \\
0.27 \\
0.59 \\
0 \\
1.53 \\
1.48\end{array}$ & $\begin{array}{l}\text { NS } \\
\text { NS } \\
\text { NS } \\
\text { NS } \\
\text { NS } \\
\text { NS }\end{array}$ \\
\hline
\end{tabular}




\section{Discussion}

Our findings confirm those of other workers that the social class of the family (classified according to the father's occupation) is the factor with the largest effect on a child's ability at $7 \frac{1}{2}$ years of age. In Oxfordshire, where all these children were born, the difference between the upper and lower classes in terms of income, housing, nutrition, and health is probably less than in any other part of Britain. Only about a dozen of the children $(5 \%)$ were attending private schools. Thus the great majority had also shared the same educational facilities for two and a half to three years.

Most of the women had been delivered before breast feeding returned to favour, and only 21 infants were still being breast fed at 2 months of age. Nevertheless, when account was taken of all the other variables breast fed children were superior in all six aspects of ability, and the difference was significant for reading and reasoning. The effect of smoking, which also shows a strong social class bias, was considerably reduced when account was taken of this; but again the difference remained in favour of non-smokers' children for all areas of ability.

Clarke noted that "subtle environmental influences can promote powerful effects within the same family" 35 ; and several studies have tended to confirm the greater than chance achievement of first born children. ${ }^{136}{ }^{37}$ In a separate sample examined at the age of 4 years we could find no differences in five sectors of development according to the child's position in the family ${ }^{38}$; but by $7 \frac{1}{2}$ years the advantages of being first born appeared to be emerging. The effects of sex also seemed to vary with age. We found that boys were more advanced than girls at the age of 6 months $^{39}$ but by 4 years the situation was reversed. ${ }^{38}$ In the present analyses the superiority of girls in reading ability at $7 \frac{1}{2}$ years was clear.

Children born to women who had been normotensive during pregnancy were not examined at $7 \frac{1}{2}$ years; but the mean scores for the children in this study were higher than those of the standardisation sample, and for some tests the difference was significant. ${ }^{40}$ Hence maternal hypertension by itself probably had not affected their development to any noticeable extent. Previously we found that treatment with methyldopa had no adverse effects on any aspect of growth or development at $7 \frac{1}{2}$ years $^{29}$; and children who had been born to women with superimposed pre-eclampsia were superior in all aspects of development, the difference being significant for perceptual matching. ${ }^{30}$ No significant differences were found in this sample between the scores for preterm and term babies; and no associations were found with birth asphyxia and problems in the neonatal period. When adjustments were made for associated variables the apparent effect of fetal distress also disappeared.

In a separate study of the development of small for dates babies (more than 2 standard deviations below the mean birth weight for gestational age and sex) they had significantly lower scores at the age of 4 years than average for dates children in all five sectors of development tested. ${ }^{41}$ But when adjustment was made for eight associated variables no significant differences remained. In this study the small for dates definition was less severe (below the 10th centile) and the children $3 \frac{1}{2}$ years older. For five out of six areas of ability the small for dates children had lower scores, but in only one was the difference significant.

After adjustment for other variables children born by emergency section had slightly higher scores than those who had had a spontaneous vaginal delivery for five out of six aspects. On the other hand, children born by elective caesarean section had lower scores in all tests. The social class distribution, sex ratio, and proportion of first to later born children did not differ in this (elective section) subgroup from the sample as a whole; and careful examination of their antenatal and postnatal histories did not disclose any other common factors which might have contributed to the poor performance of these children at the age of $7 \frac{1}{2}$.

Perinatal mortality in the "special risk" group had been 10 times greater than in the rest of the sample. Among the mothers of survivors eight had had severe hypertension when first seen. Two women with essential hypertension had been taking methyldopa for two and four years, respectively; and one of the pregnancies had been induced with clomiphene. Associated medical problems were diabetes mellitus (two cases), rhesus incompatibility with rising titres (two), disseminated lupus erythematosus (one), the nephrotic syndrome with progressive renal failure (one), and severe arthritis of the hip with gross obesity (one). Seven women were delivered by elective section, two by emergency section, and there were nine vaginal deliveries. Twelve deliveries were preterm and only six occurred after 37 weeks of gestation. Fourteen of these children $(78 \%$ ) had had problems in the neonatal period; and there was an unusually high sex ratio among the survivors ( 14 boys, 4 girls). Yet despite an accumulation of prenatal and perinatal risk factors, the children in this group who survived did not differ from the remainder. Our findings do not support the notion that there is a "continuum of reproductive casualty." 42 On the contrary, they indicate that children who survive a highly adverse intrauterine environment with subsequent complications at delivery and in the neonatal period are no more likely to have developmental problems in childhood than those whose early biographies had been much less hazardous.

This work is supported by a Medical Research Council (UK) programme grant. Merck Sharp and Dohme Ltd also gave financial help.

\section{References}

${ }^{1}$ Davie R, Butler N, Goldstein H. From birth to seven. London: Longman, 1972.

${ }^{2}$ Fisch RO, Bilek MK, Horrobin JM, Chang Pi-Nian. Children with superior intelligence at 7 years of age. Am 7 Dis Child 1976;130:481-7.

${ }^{3}$ Prechtl HFR. Neurological sequelae of prenatal and perinatal complications. Br Med $\mathcal{F} 1967$;iv:763-7.

${ }^{4}$ Prechtl HFR. The optimality concept. Early Hum Dev 1980;4:201-5.

5 Touwen BCL. Neurological follow-up of infants born after obstetrical complications. In: Stoelinga GBA, Werff ten Bosch VD, eds. Normal and abnormal development of brain and behaviour. Leiden: University Press, 1971:179-86.

6 Touwen BCL. The relationship between neonatal and follow-up findings. In: Saling E, Schulte FJ, eds. Perinatal medizin. Vol 2. Stuttgart: Georg-Thieme Verlag, 1972:303-6.

${ }^{7}$ Kalveboer AF, Touwen BCL, Prechtl HFR. Follow-up of infants at risk of minor brain dysfunction. In: De La Cruz FF, Fox BH, Roberts RH, eds. Minimal brain dysfunction. New York: New York Academy of Sciences, 1973:173-87.

${ }^{8}$ Saugstat LF. The influence of obstetric complications on the clinical picture in classical phenylketonuria. Fournal of Clinical Genetics 1973; 4:115-24.

${ }^{9}$ Littman B, Parmalee AH. Medical correlates of infant development. Pediatrics $1978 ; 61: 470-4$.

${ }^{10}$ Hardy JB, Mellits ED. Does maternal smoking during pregnancy have a long-term effect on the child ? Lancet 1972 ;ii:1332-6.

${ }^{11}$ Butler NR, Goldstein H. Smoking in pregnancy and subsequent child development. Br Med $\mathcal{f} 1973$;iv:573-5.

12 Lefkowitz MM. Smoking during pregnancy: long-term effects on offspring. Developmental Psychology 1981;17:192-4.

${ }^{13}$ McBride WG, Black BP, Brown CJ, Dolby RM, Murray AD, Thomas DB. Method of delivery and developmental outcome at 5 years of age. Med f Aust 1979; ;:301-4.

14 Silva PA, Buckfield P, Spears GF. Mode of delivery and developmental characteristics in a thousand Dunedin three year olds. NZ Med F 1979; 89:79-81.

15 Dweck HS, Huggins W, Dorma LP, Sayon SA, Benton JW, Cassady G. Developmental sequelae in infants having suffered severe perinatal asphyxia. Am F Obstet Gynecol 1974;119:811-5.

${ }^{16}$ Niswander KR, Gordon M, Drage JS. The effect of intrauterine hypoxia on the child surviving to 4 years. Am 7 Obstet Gynecol 1975;121:892-9.

17 Addy DP. Birth asphyxia. Br Med f 1982;284:1288-9.

18 Rubin RA, Balow B, Fisch RO. Neonatal serum bilirubin levels related to cognitive development at ages 4 through 7 years. $\mathcal{F}$ Pediatr 1979; $94: 601-4$.

19 Menkes JH. Early feeding history of children with learning disorders. Dev Med Child Neurol 1977;19:169-71.

${ }^{20}$ Rodgers B. Feeding in infancy and later ability attainment: a longitudinal study. Dev Med Child Neurol 1978;20:421-6.

${ }^{21}$ Stewart AL, Reynolds EOR. Improved diagnosis for infants of very low birthweight. Pediatrics $1974 ; 54: 724-35$.

${ }^{22}$ Francis-Williams J, Davies PA. Very low birthweight and later intelligence. Dev Med Child Neurol 1974;16:709-28. 
${ }^{23}$ Fitzhardinge PM, Steven EM. The small-for-date infant: neurologica and intellectual sequelae. Pediatrics 1972;50:50-7.

24 Neligan GA, Kolvin I, Scott DM, Garside RF. Born too soon, born too small. Clinics in developmental medicine. No 61. London: Spastics International Medical Publications, Heinemann, 1976.

${ }^{25}$ Redman CWG, Beilin LJ, Bonnar J, Ounsted MK. A trial of antihypertensive treatment in pregnancy: fetal outcome. Lancet 1976;ii:753-6.

${ }^{26}$ Mutch LMM, Moar VA, Ounsted MK, Redman CWG. Hypertension during pregnancy with and without specific hypotensive treatment. i, Perinatal and postnatal factors. Early Hum Dev 1977;1:47-57.

27 Mutch LMM, Moar VA, Ounsted MK, Redman CWG. Hypertension during pregnancy with and without specific hypotensive treatment. $\mathrm{ii}$, The growth and development of the infant in the first year of life. Early Hum Dev 1977;1:59-67.

28 Ounsted MK, Moar VA, Good FJ, Redman CWG. Hypertension during pregnancy with and without specific treatment; the development of the children at the age of four years. Br $\mathcal{F}$ Obstet Gynaecol $1980 ; 87$ : 19-24.

${ }^{2 y}$ Cockburn J, Moar VA, Ounsted M, Redman CWG. Final report of study on hypertension during pregnancy: the effects of specific treatment on the growth and development of the children. Lancet $1982 ; \mathrm{i}$ : 647-9.

${ }^{30}$ Ounsted M, Cockburn J, Moar VA, Redman CWG. Maternal hypertension with superimposed pre-eclampsia: effects on child development at $7 \frac{1}{2}$ years. Br $\mathcal{F}$ Obstet Gynaecol 1983;90:644-9.

${ }^{31}$ Elliott CD, Murray DJ, Pearson LS. The British ability scales. Windsor: NFER Publishing Company Ltd, 1978.

32 Ounsted M, Moar V, Scott A. Perinatal morbidity and mortality in small-for-dates babies: the relative importance of some maternal factors. Early Hum Dev 1981 ;5:367-75.
${ }^{33}$ Scott A, Moar V, Ounsted M. The relative contributions of different maternal factors in small-for-gestational-age pregnancies. Eur $\mathcal{F}$ Obstet Gynaecol Reprod Biol 1981;12:157-65.

${ }^{34}$ Scott A, Moar V, Ounsted M. The relative contributions of different maternal factors in large-for-gestational-age pregnancies. Eı⿱r $\mathfrak{f}$ Obstet Gynaecol Reprod Biol 1982;13:269-77.

${ }^{35}$ Clarke ADB. Consistency and variability in the growth of human characteristics. Dev Med Child Neurol 1972;14:669-83.

${ }^{36}$ Stone FH. Birth order, intelligence and personality. Dev Med Child Neurol 1969;11:647-8.

37 Altus WD. Birth order and its sequelae. Science 1966;151:44-9.

38 Ounsted MK, Osborn ML, Sleigh G, Good FJ. A method of developmental assessment at four years and some associated findings. Early Hum Dev 1979;3:1-19.

${ }^{39}$ Ounsted M. Basics: size at birth and its effect on growth and development in the first year of life. In: Apley J, Ounsted C, eds. One child. London: Heinemann, 1982:84-121. (Clinics in Developmental Medicine, No 80.)

"0 Cockburn J, Ounsted M. The British ability scales: some differences between scores for Oxfordshire children and the standardization sample. Bulletin of the British Psychological Society 1983;36:83-4.

"1 Ounsted M, Moar VA, Scott A. Small for dates babies at the age of four years: health, handicap and developmental status. Early Hum Dev $1983 ; 8: 243-58$.

${ }^{12}$ Lilienfeld AM, Pasamanick B, Rogers M. Relationship between pregnancy experience and the development of certain neuro-psychiatric disorders in childhood. Am $\mathcal{F}$ Public Health 1955 ;45:637-43.

(Accepted 8 February 1984)

\section{SHORT REPORTS}

\section{Intravenous infusion of frusemide as treatment for ascites in malignant disease}

Continuous intravenous infusion of frusemide is useful in the management of renal failure and congestive cardiac failure. ${ }^{12} \mathrm{We}$ report on an adaptation of the technique for the rapid relief of patients with tense ascites associated with malignant disease.

\section{Case reports}

Case 1-A 66 year old woman with a serous papillary cystadenocarcinoma of the ovary without liver metastases presented with ascites that yielded positive results on cytological examination. Her condition failed to improve despite chemotherapy with cisplatin, chlorambucil, and cyclopenthiazide $0.75 \mathrm{mg}$ daily with potassium. Ascites continued to accummulate over three weeks, causing abdominal distension, dyspnoea, and weight gain of $5 \mathrm{~kg}$. She received spironolactone $100 \mathrm{mg}$ twice daily and frusemide $100 \mathrm{mg}$ given as an intravenous infusion over 24 hours in a total volume of $48 \mathrm{ml}$ physiological saline; diuresis of 2.841 occurred during the infusion, and she lost $7.7 \mathrm{~kg}$ in weight over the next 10 days.

Case 2-A 42 year old woman with carcinoma of the breast, liver metastases, and hypoalbuminaemia $(27 \mathrm{~g} / \mathrm{l}$, normal range $>30 \mathrm{~g} / \mathrm{l})$, did not respond to cytotoxic treatment and had tense ascites. The fluid had a protein content of $7 \mathrm{~g} / \mathrm{l}$ and yielded a negative result on cytological examination. After one week's treatment with frusemide $120 \mathrm{mg}$ daily by mouth and spironolactone $100 \mathrm{mg}$ daily there was no reduction of ascites. Frusemide $100 \mathrm{mg}$ in $500 \mathrm{ml}$ physiological saline was then infused intravenously over 24 hours and produced a diuresis of $2700 \mathrm{ml}$, weight loss of $1.8 \mathrm{~kg}$, a decrease in abdominal girth of $4.5 \mathrm{~cm}$, and complete resolution of the signs and symptoms of ascites. Ascites had not returned at the time of her death six weeks later.

Case 3-A 35 year old woman with hepatic metastases from carcinoma of the breast and deranged liver function (albumin concentration $25 \mathrm{~g} / \mathrm{l}$ ) presented with tense ascites. Frusemide $100 \mathrm{mg}$ daily and spironolactone $100 \mathrm{mg}$ daily gave no relief after 48 hours. Frusemide $100 \mathrm{mg}$ in $100 \mathrm{ml}$ physiological saline was infused intravenously by a syringe pump at a rate of $5 \mathrm{ml} / \mathrm{h}$. By 16 hours she had achieved a diuresis of $1060 \mathrm{ml}$, weight loss of $1.9 \mathrm{~kg}$, and a reduction in abdominal girth of $2 \mathrm{~cm}$. She was discharged taking frusemide $40 \mathrm{mg}$ and spironolactone $100 \mathrm{mg}$ daily by mouth; 19 days after the infusion her total reduction in girth was $11 \mathrm{~cm}$. The primary tumour did not respond subsequently to chemotherapy, but ascites did not recur.

Case 4-A 61 year old woman with carcinoma of the breast and hepatic metastases had ascites that yielded a negative result on cytological examination. Paracentesis of 31 had been followed by deterioration of liver function (albumin concentration $29 \mathrm{~g} / \mathrm{l}$ ). The ascites reaccummulated and was unresponsive to oral spironolactone $200 \mathrm{mg}$ and frusemide $80 \mathrm{mg}$ daily. Frusemide $100 \mathrm{mg}$ in $500 \mathrm{ml}$ physiological saline was infused intravenously over 24 hours and led to a diuresis of $1600 \mathrm{ml}$, weight loss of $1.4 \mathrm{~kg}$, and reduction in abdominal girth of $5.5 \mathrm{~cm}$. The infusion was repeated 48 hours later with complete clinical resolution of ascites.

\section{Comment}

These four patients with intra-abdominal malignancy sustained immediate relief of ascites after the intravenous infusion of frusemide. The major reductions in symptoms and girth measurements were associated with a fairly small diuresis, suggesting a redistribution of body fluids as well as an absolute loss. The presence or absence of hepatic dysfunction did not affect outcome. The procedure was well tolerated, and there were no appreciable electrolyte disturbances, probably because of the small dose of frusemide given in only a short time by this technique. ${ }^{3}$ It is more logical to minimise the volume of saline given by infusing more concentrated frusemide solutions with the aid of an electric pump, as was done in cases 1 and 3 . The procedure was free of the hazards of paracentesis and more effective than giving an oral diuretic. It offers a useful treatment for this distressing complication of malignant disease.

${ }^{1}$ Allison MFH, Kennedy AC. Diuretics in chronic renal disease: a study of high dosage frusemide. Clin $S_{c i} 1971 ; 41: 171-87$.

${ }^{2}$ Gray JMB, Henry DA, Lawson DH, Tilstone WJ. Continuous infusion of frusemide in refractory oedema. Br 7 Clin Pharmacol 1978;6:461P.

${ }^{3}$ Fogel MR, Sawhney VK, Neal A, Miller RG, Knauer CM, Gregory PB. Diuresis in the ascitic patient: a randomized controlled trial of three regimens. F Clin Gastroenterol 1981 ;3,suppl 1:73-80.

(Accepted 19 fanuary 1984)

Imperial Cancer Research Fund Breast Cancer Unit and Medical

Oncology Clinic, Guy's Hospital, London SE1 9RT

STEPHANIE A AMIEL, MB, MRCP, registrar

ANN $M$ BLACKBURN, MD, MRCP, lecrurer in medicine

ROBERT D RUBENS, MD, MRCP, consultant physician

Correspondence to: Dr R D Rubens. 